\title{
Role of the Pharmacist in Managing Antidepressant Drug Interactions in the Solid Organ Transplant Population
}

\author{
Suzanne C Harris ${ }^{1 *}$ and Chaz Hyatt ${ }^{2}$ \\ ${ }^{1}$ Division of Practice Advancement and Clinical Education, University of North Carolina Eshelman School of Pharmacy, USA \\ ${ }^{2}$ Department of Pharmacy, University of North Carolina Medical Center, USA
}

*Corresponding author: Suzanne C Harris, Division of Practice Advancement and Clinical Education, University of North Carolina Eshelman School of Pharmacy, USA.

\begin{abstract}
Major depressive disorder (MDD) is prevalent in solid organ transplant (SOT) patients and can lead to medication nonadherence and risk of rejection of the transplant organ. In addition, pharmacokinetic and pharmacodynamic drug interactions can pose challenges when using antidepressant and immunosuppressant medication concomitantly. Clinical pharmacists serve an important role in improving patient outcomes in SOT patients with depression by predicting and avoiding potential drug interactions, identifying when drug interactions warrant modifications, and educating patients and providers on safe and effective use of antidepressants in the transplant population.
\end{abstract}

Keywords: Pharmacist; Transplant; Depression; Antidepressant; Immunosuppressant; Interaction

Abbreviations: MDD: Major Depressive Disorder: SOT: Solid Organ Transplant; CYP: Cytochrome P450; SSRI: Selective Serotonin Reuptake Inhibitors; SNRI: Selective Serotonin and Norepinephrine Reuptake Inhibitors; DDI: Drug-Drug Interactions; CNS: Central Nervous System; PGP:

P-glycoprotein; TCA: Tricyclic Antidepressants; MAOI: Monoamine Oxidase Inhibitors

\section{Introduction}

In transplant patients, Major Depressive Disorder (MDD) is the most prevalent psychiatric disorder and is associated with reduced quality of life, with prevalence rates of MDD in up to $25 \%$ of solid organ transplant (SOT) patients [1]. MDD can lead to medication nonadherence, which can cause rejection of the transplant organ. Additionally, antidepressant medications have a range of unique side effects and potential for pharmacokinetic and pharmacodynamic interactions. Many of the transplant medications are metabolized by cytochrome P450 3A4 enzymes, putting them at risk for pharmacokinetic drug interactions. In addition, these medications can have pharmacodynamic interactions with antidepressants. Corticosteroids can cause weight gain, leading to diabetes and obesity. Cyclosporine causes hypertension in $50 \%$ of kidney transplant patients. Tacrolimus and cyclosporine have been reported to have central nervous toxicity in one-third of patients. Corticosteroids, sirolimus, and cyclosporine have been associated with hyperlipidemia [2]. Hence, these interactions with antidepressants can result in altered concentrations of immunosuppressants or additive untoward side effects (Table 1).

Table 1 lists potential drug-drug interactions, notable side effects and precautions, and important points for consideration when combining antidepressants and immunosuppressant agents [2-5]. Clinical pharmacists have expertise in evaluating the clinical relevance of potential drug interactions and providing recommendations to reduce risks when warranted, ultimately helping to improve tolerability and clinical outcomes in SOT patients. 
Table 1: Drug Interactions and Clinical Pearls of Antidepressants in SOT patients.

\begin{tabular}{|c|c|c|c|}
\hline & Metabolism/DDI Potential & Notable Side Effects, Precautions, or Pearls & $\begin{array}{c}\text { Considerations in Solid Organ Trans- } \\
\text { plant Population }\end{array}$ \\
\hline Citalopram (Celexa) & $\begin{array}{l}\text { Substrate: CYP2C19 (major), } \\
\text { CYP2D6 (minor), CYP3A4. Weak } \\
\text { inhibitor of CYP2D6. }\end{array}$ & $\begin{array}{l}\text { Dose dependent QTc prolongation. Caution in dos- } \\
\text { es higher than } 40 \mathrm{mg}\end{array}$ & $\begin{array}{c}\text { Favorable drug interaction profile, use } \\
\text { caution with other QTc prolonging } \\
\text { agents. }\end{array}$ \\
\hline $\begin{array}{l}\text { Escitalopram } \\
\text { (Lexapro) }\end{array}$ & $\begin{array}{l}\text { Substrate: CYP2C19 (major), } \\
\text { CYP3A4 (major). Weak inhibitor } \\
\text { of CYP2D6 }\end{array}$ & Use $10 \mathrm{mg}$ daily in hepatic impairment. & $\begin{array}{l}\text { Favorable drug interaction and side } \\
\text { effect profile. Preferred agent. }\end{array}$ \\
\hline Fluoxetine (Prozac) & $\begin{array}{l}\text { Substrate: CYP2C9 (major). In- } \\
\text { hibits CYP2D6, CYP3A4, CYP2C9, } \\
\text { and CYP2C19. }\end{array}$ & $\begin{array}{l}\text { High drug interaction potential. Low-moderate } \\
\text { inhibition of CYP3A4. Long half-life. }\end{array}$ & $\begin{array}{l}\text { High drug interaction potential with } \\
\text { calcineurin inhibitors and sirolimus. } \\
\text { Use caution. }\end{array}$ \\
\hline Fluvoxamine (Luvox) & $\begin{array}{l}\text { Substrate: CYP1A2, CYP2D6. } \\
\text { Inhibits CYP1A2, CYP2C19, } \\
\text { CYP3A4, CYP2D6 }\end{array}$ & Strongest inhibition of CYP3A4 among SSRIs. & Do not use in transplant patients. \\
\hline Paroxetine (Paxil) & $\begin{array}{c}\text { Substrate: CYP2D6. Inhibits } \\
\text { CYP2D6, CYP2C9, CYP2C19, and } \\
\text { CYP3A4. }\end{array}$ & $\begin{array}{l}\text { Anticholinergic side effects (weight gain). Short } \\
\text { half-life, high potential for withdrawal. Medium } \\
\text { inhibition of CYP3A4 among SSRIs. }\end{array}$ & $\begin{array}{l}\text { Renal and hepatic adjustments are } \\
\text { necessary. Higher weight gain potential } \\
\text { than other SSRIs. }\end{array}$ \\
\hline Sertraline (Zoloft) & $\begin{array}{l}\text { Substrate: Many CYPs (minor). } \\
\text { Weakly inhibits CYP2D6. }\end{array}$ & $\begin{array}{l}\text { Increased potential for GI side effects. Hepatic } \\
\text { adjustment may be necessary. }\end{array}$ & $\begin{array}{l}\text { Favorable drug interaction and side } \\
\text { effect profile. Preferred agent. }\end{array}$ \\
\hline
\end{tabular}

Selective Serotonin and Norepinephrine Reuptake Inhibitors (SNRIs): Have similar side effects as SSRIs as well as additional cardiovascular side effects, which are dose-related with venlafaxine. These additional side effects are increased hypertension and heart rate and are related to increased levels of norepinephrine.

\begin{tabular}{|c|c|c|c|}
\hline & Metabolism/DDI Potential & Notable Side Effects, Precautions, or Pearls & $\begin{array}{l}\text { Considerations in Solid Organ Trans- } \\
\text { plant Population }\end{array}$ \\
\hline $\begin{array}{l}\text { Duloxetine (Cym- } \\
\text { balta) }\end{array}$ & $\begin{array}{l}\text { Substrate: CYP1A2, CYP2D6. } \\
\text { Moderately inhibits CYP2D6. }\end{array}$ & $\begin{array}{l}\text { Renal adjustments necessary. Avoid use in hepatic } \\
\text { impairment and } \mathrm{CrCl} \leq 30 \mathrm{~mL} / \mathrm{min} \text {. }\end{array}$ & $\begin{array}{l}\text { Use with caution in kidney, liver, and } \\
\text { heart transplant due to side effects and } \\
\text { potential organ impairment. }\end{array}$ \\
\hline Venlafaxine (Effexor) & $\begin{array}{l}\text { Substrate: CYP2D6, CYP3A4 } \\
\text { (major). Weakly inhibits some } \\
\text { CYP enzymes, low potential for } \\
\text { interactions. }\end{array}$ & $\begin{array}{l}\text { Renal and hepatic adjustments necessary. Can } \\
\text { cause palpitations and tachycardia. }\end{array}$ & $\begin{array}{l}\text { Can cause dose related hypertension, } \\
\text { use caution with cyclosporine. }\end{array}$ \\
\hline $\begin{array}{r}\text { Levomil } \\
\quad \text { Fetz }\end{array}$ & Substrate: CYP3A4, PGP. & potential for drug-drug ir & $\begin{array}{r}\text { Newer agent. } 1 \\
\text { use in transplan }\end{array}$ \\
\hline \multicolumn{4}{|c|}{ Miscellaneous } \\
\hline & Metabolism/DDI Potential & Notable Side Effects, Precautions, or Pearls & $\begin{array}{l}\text { Considerations in Solid Organ Trans- } \\
\text { plant Population }\end{array}$ \\
\hline $\begin{array}{l}\text { Mirtazapine (Rem- } \\
\text { eron) }\end{array}$ & Substrate: CYP3A4, PGP. & $\begin{array}{l}\text { Less sexual dysfunction, increased weight gain } \\
\text { appetite stimulation, and somnolence. Reports of } \\
\text { increase in triglycerides and potential hyperlip- } \\
\text { idemia. }\end{array}$ & $\begin{array}{l}\text { Favorable DDI profile. Sedation and } \\
\text { weight gain could be used advanta- } \\
\text { geously. May cause additive weight } \\
\text { gain, hyperlipidemia when used with } \\
\text { transplant medications. }\end{array}$ \\
\hline $\begin{array}{l}\text { Bupropion (Well- } \\
\text { butrin) }\end{array}$ & $\begin{array}{l}\text { Substrate: CYP2B6, plus others } \\
\text { (minor). Inhibits CYP2D6 } \\
\text { (strong). }\end{array}$ & $\begin{array}{l}\text { Less weight gain and sexual dysfunction than } \\
\text { other antidepressants. Can lower seizure thresh- } \\
\text { old, especially in high doses and in patients with } \\
\text { eating disorders or epilepsy. Can be activating and } \\
\text { worsen insomnia if dosed close to bedtime. }\end{array}$ & $\begin{array}{l}\text { Patients should be carefully assessed } \\
\text { for CNS toxicity prior to starting bupro- } \\
\text { pion, specifically regarding history of } \\
\text { seizures. }\end{array}$ \\
\hline $\begin{array}{l}\text { Vortioxetine (Trin- } \\
\text { tellix) }\end{array}$ & Substrate: CYP2D6, CYP3A4. & $\begin{array}{l}\text { Dose modification necessary for CYP2D6 inhibi- } \\
\text { tors/inducers or poor metabolizers. Nausea in up } \\
\text { to } 30 \% \text { of patients. }\end{array}$ & $\begin{array}{l}\text { Newer agent. Minimal DDI, however } \\
\text { use in transplant is not yet established. }\end{array}$ \\
\hline Vilazodone (Viibryd) & Substrate: CYP3A4. & $\begin{array}{l}\text { Dose modification for CYP3A4 inhibitors. Nausea } \\
\text { in } \sim 20 \% \text { and diarrhea in up to } 29 \% \text { of patients. }\end{array}$ & $\begin{array}{l}\text { Newer agent. Minimal DDI, however } \\
\text { use in transplant is not yet established. }\end{array}$ \\
\hline \multicolumn{4}{|c|}{$\begin{array}{l}\text { Tricyclic antidepressants (TCAs): Have increased side effect profile when compared with other antidepressants. TCAs are associated with QRS prolon- } \\
\text { gation, Afib, acute MI, and ventricular tachycardia, ruling out cardiac transplant patients. Anticholinergic side effects such as orthostatic hypotension, } \\
\text { sedation, and weight gain are also prevalent. Seizure activity has also been reported at therapeutic doses. Use for refractory cases of MDD }\end{array}$} \\
\hline \multicolumn{4}{|c|}{$\begin{array}{l}\text { Monoamine Oxidase Inhibitors (MAOIs): Can cause hypertensive crisis, especially when combined with other drugs (including OTC pseudoephedrine). } \\
\text { Have the highest risk for serotonin syndrome among antidepressants. Requires a strict diet adherence; patients cannot eat foods with tyramine in them. } \\
\text { These interactions with food and other drugs can be potentially fatal. Use for refractory cases only. }\end{array}$} \\
\hline \multicolumn{4}{|c|}{$\begin{array}{l}\text { St. John's Wort: While there may be some evidence that St. John's wort is efficacious in depression, it should not be used. Induces CYP1A2, 2B6, 2C9, } \\
\text { 2C19, 3A4, phase II metabolism enzymes, and PGP. Causes many various types of drug interactions with transplant medications. Cases of acute organ } \\
\text { rejection due to St. John's wort have been seen. }\end{array}$} \\
\hline
\end{tabular}




\section{Discussion}

Clinical pharmacists on consult liaison psychiatry, medical, or surgical teams actively participate in the medication management of solid organ transplant recipients, including the management of agents to treat depression in these patients. While most antidepressants are safe and well-tolerated, careful considerations of potential and clinically relevant interactions must be made in the recommendation of initial antidepressants or in modification of antidepressant regimens in SOT patients. Also, depending on where the patient is in the transplant process, different drug interactions may be more important. Pre-transplant concerns when initiating antidepressants may vary from clearance and metabolism of the antidepressant, or negative effects on the impaired organ. Posttransplant concerns when initiating antidepressants include inhibition or induction of immunosuppressants, or additive side effects to immunosuppressants regardless of metabolism; hence, careful monitoring of immunosuppressant levels or worsening of adverse effects may be necessary during the post-transplant phase. Newer antidepressants may have favorable CYP P450 drug interaction profiles when combined with immunosuppressants, however lack of established data in SOT patients limit their use.

\section{Conclusion}

Clinical pharmacists serve an important role in improving patient outcomes in SOT patients with depression by predicting and avoiding potential drug interactions, identifying when drug interactions warrant modifications, and educating patients and providers on safe and effective use of antidepressants in the transplant population.

\section{Acknowledgement}

None

\section{Conflict of Interest}

No authors have any conflicts of interest to disclose.

\section{References}

1. Dew MA, Kormos RL, Dimartini AF, Switzer GE, Schulberg HC, et al. (2001) Prevalence and risk of depression and anxiety-related disorders during the first three years after heart transplantation. Psychosomatics 42(4):300-313.

2. Kim J, Phongsamran P, Park S (2019) Use of antidepressant drugs in transplant recipients. Prog Transplant 14(2):98-104.

3. Kahl KG, Eckermann G, Frieling H, Hillemacher T (2019) Psychopharmacology in transplantation medicine. Prog Neuropsychopharmacol Biol Psychiatry 88:74-85.

4. Teter CJ, Kando JC, Wells BG Major Depressive Disorder. In: DiPiro JT, Talbert RL, Yee GC, Matzke GR, Wells BG, Posey L (Eds.) Pharmacotherapy: A Pathophysiologic Approach, 10e, McGraw-Hill; New York, USA.

5. Lexicomp Online. Lexi-Comp, Inc (Copyright 1978-2016). 